\title{
Genomic damage induced by the widely used fungicide chlorothalonil in peripheral human lymphocytes
}

\author{
Alfredo Santovito*, Claudio Gendusa, Francesca Ferraro, Irene Musso, Maria Costanzo, \\ Stefano Ruberto, Piero Cervella \\ University of Turin, Department of Life Sciences and Systems Biology, Via Accademia Albertina n. 13, 10123 Torino, Italy
}

\section{A R T I C L E I N F O}

\section{Keywords:}

Chromosomal aberrations

Genotoxicology

Micronuclei

Pesticide

\begin{abstract}
A B S T R A C T
Chlorothalonil is an important broad spectrum fungicide widely used in agriculture, silviculture, and urban settings. As a result of its massive use, chlorothalonil was found in all environmental matrices, with consequent risks to the health of terrestrial and aquatic organisms, as well as for humans.

We analyzed the effects of chlorothalonil on human lymphocytes using in vitro chromosomal aberrations (CAs) and micronuclei (MNi) assays. Lymphocytes were exposed to five concentrations of chlorothalonil: $0.600 \mu \mathrm{g} / \mathrm{mL}, 0.060 \mu \mathrm{g} / \mathrm{mL}, 0.030 \mu \mathrm{g} / \mathrm{mL}, 0.020 \mu \mathrm{g} / \mathrm{mL}$, and $0.015 \mu \mathrm{g} / \mathrm{mL}$, where 0.020 and $0.600 \mu \mathrm{g} / \mathrm{mL} \mathrm{re-}$ present the ADI and the ARfD concentration values, respectively, established by FAO/WHO for this compound; 0.030 and $0.060 \mu \mathrm{g} / \mathrm{mL}$ represent intermediate values of these concentrations and $0.015 \mu \mathrm{g} / \mathrm{mL}$ represents the ADI value established by the Canadian health and welfare agency.

We observed cytogenetic effects of chlorothalonil on cultured human lymphocytes in terms of increased CAs and MNi frequencies at all tested concentrations, including the FAO/WHO ADI and ARfD values of 0.020 and $0.600 \mu \mathrm{g} / \mathrm{mL}$, respectively, but with exception of the Canadian ADI value of $0.015 \mu \mathrm{g} / \mathrm{mL}$.

Finally, no sexes differences were found in the levels of CAs and MNi induced by different chlorothalonil concentrations. Similarly, the mitotic index and the cytokinesis-block proliferation index did not show any significant effect on the proliferative capacity of the cells, although at the chlorothalonil concentration of $0.600 \mu \mathrm{g} / \mathrm{mL}$ the $P$-values of both indices were borderline.
\end{abstract}

\section{Introduction}

Chlorothalonil (CHT) is a broad spectrum, non-systemic chlorinated isophtalonitrile fungicide widely used in agriculture, silviculture, and urban settings. It reacts with functional cellular thiols and inhibits fungal respiration and energy metabolism. For this reason, it was used to control fungal and bacterial infestations in many fruit, vegetable and agricultural crops including peanuts, tomatoes, potatoes, onions and celery (FAO/WHO, 2010).

As a result of its massive use, CHT was found in all environmental matrices (Arinaitwe et al., 2016; Wu et al., 2014) and its possible genotoxicity has been investigated by many authors. CHT was found to be relatively non-toxic for avian species, small mammals and honeybees, but highly toxic for fish, crustaceans, amphibians and aquatic invertebrates (Du Gas et al., 2017; Gallo and Tosti, 2015; Guerreiro et al., 2017; Yu et al., 2013). Moreover, in rodents, chronic dietary exposure to CHT was found to cause an increased incidence of papillomas and carcinomas of the stomach squamous epithelium as well as of adenomas and carcinomas of the renal proximal tubule epithelium (FAO/WHO, 1992).

In humans, CHT exposure was associated with contact dermatitis, severe eye and skin irritation and gastrointestinal problems. In particular, allergic contact dermatitis, conjunctivitis and upper airway complaints were described in fruit and vegetable growers (Penagos et al., 2004), in floriculturists and in trailer tent factory workers (Lensen et al., 2007, 2011). Vice versa, epidemiological evidences for an association between CHT and different type of cancers, such as colon, lung, and prostate cancers among humans were not found (Mozzachio et al., 2008).

Form genotoxic point of view, in vivo results showed that, mice and Chinese hamsters chronically treated with CHT revealed increased levels of DNA damage in terms of chromosomal aberrations (CAs) and sister chromatid exchanges (SCEs) (Dearfield et al., 1993). Moreover, Lebailly et al. (1998), using the alkaline comet assay, observed increased levels of DNA damage in mononuclear leukocytes of farmers exposed to selected pesticides, including CHT.

\footnotetext{
* Corresponding autrhor.

E-mail address: alfredo.santovito@unito.it (A. Santovito).
} 
On the other hand, in vitro studies showed that CHT failed to induce CAs and micronuclei (MNi) in mammalian cell lines (Vigreux et al., 1998), whereas positive results in terms of loss of cell viability and increased frequencies of damaged cells were found in human peripheral blood lymphocytes analyzed with the SCGE assay (Lebailly et al., 1997).

Based on evidences of carcinogenicity from animal studies but no from human epidemiologic data, CHT was classified by U.S. Environmental Protection Agency (EPA) as a Group B2 (probable human carcinogen) (EPA, 1999). Similarly, the International Agency for Research on Cancers (IARC), despite the lack of available data about human carcinogenicity, classified $\mathrm{CHT}$ as a possible carcinogen (2B) (IARC, 1999). Different FAO/WHO reviews confirmed that CHT did not show a genotoxic hazard for humans and, on the basis of the available information, estimated the Acceptable Daily Intake (ADI) value to $0-0.02 \mathrm{mg} / \mathrm{kg} / \mathrm{bw}$ and the Acceptable Reference Dose value to $0.6 \mathrm{mg}$ / $\mathrm{kg} / \mathrm{bw}$ (FAO/WHO, 2010). However, it should be emphasized that, in a previous published report and partially in contrast to FAO/WHO, the Canadian health and welfare agency established for CHT the more stringent ADI concentration value of $0-0.015 \mathrm{mg} / \mathrm{kg} / \mathrm{bw}$ (HWC, 1994).

The widespread use of CHT in agriculture and the limited data about its genotoxicity in humans lymphocytes, prompted us to investigate the frequency of CAs and MNi in human peripheral lymphocytes after in vitro exposure to different concentrations of this pesticide, including the ADI-value and the Acceptable Reference Dose (ARfD) established by FAO/WHO, as well as the ADI-value established by the Canadian health and welfare agency.

Among cytogenetic test systems, CAs and MNi assays are important tools in the measurement of the genotoxic potential of many chemicals. The CAs assay allows the detection of cells carrying unstable aberrations (i.e. chromosome/chromatid breaks, fragments, rings and dicentrics) that will lead to cell death during proliferation (GarciaSagredo, 2008). On the other hand, MNi assay allows evaluation of both potential clastogenic and/or aneugenic effects of different xenobiotics. In particular, $\mathrm{MNi}$ originates from acentric chromosome fragments or whole chromosomes that fail to segregate properly during mitotic division and appear in the cytoplasm of interphase cells as small additional nuclei (Fenech, 2016). Interestingly, previous published studies provided evidences for a relationship between high levels of CAs and $\mathrm{MNi}$ in peripheral blood lymphocytes and increase of cancer risk (Bonassi et al., 2004, 2011).

\section{Materials and methods}

\subsection{Chemicals and reagents}

The IUPAC name of CHT is: Tetrachloroisophthalonitrile (CAS no. 1897-45-6). The CHT (obtained from Labservices, Bologna, Italy) was first dissolved in dimethyl sulfoxide (DMSO) (CAS no. 67-68-5) at a final concentration of $0.6 \mathrm{mg} / \mathrm{mL}$ (stock solution) and was kept at $4{ }^{\circ} \mathrm{C}$ until prepared for the final exposure solutions in culture medium. Gibco RPMI 1640 cell culture media supplemented with L-glutamine, foetal calf serum, phytohemagglutinin (PHA), and antibiotics were purchased from Invitrogen-Life Technologies, Milan, Italy. Cytochalasin-B, colchicine and Mitomycin-C (MMC) were obtained from Sigma-Aldrich, Milan, Italy. Methanol, Acetic acid, Giemsa stain solution, and conventional microscope slides were purchased from Carlo Erba Reagenti, Milan, Italy. Potassium chloride $(\mathrm{KCl})$ and Sörensen buffer were obtained from Merck S.p.A., Milan, Italy. Vacutainer blood collection tubes were from Terumo Europe, Rome, Italy. Distilled water was used throughout the experiments.

\subsection{Subjects}

Peripheral venous blood was collected from 6 healthy subjects ( 3 males and 3 females, mean age \pm S.E., $32.90 \pm 1.84$, range 23-40 years), non-smoking, not alcoholics, not under drug therapy, and with no recent history of exposure to mutagens. Informed consent was obtained from all blood donors. The study was approved by the local ethics committee and was performed in accordance with the ethical standards laid down in the 1964 Declaration of Helsinki.

\subsection{Blood sample collection and lymphocyte cultures}

Blood samples were obtained by venepuncture (about $10 \mathrm{~mL}$ of blood per subject), collected in heparinised tubes, cooled $\left(4^{\circ} \mathrm{C}\right)$ and processed within $2 \mathrm{~h}$ after collection. Heparinised venous blood $(0.3 \mathrm{~mL})$ were cultured in $25 \mathrm{~cm}^{2}$ flasks containing $6 \mathrm{~mL}$ of RPMI-1640 medium, $2 \mathrm{~mL}$ of foetal calf serum (FCS), $200 \mu \mathrm{L}$ of the mitogenic agent Phytohemagglutinin-L $(2.3 \% \mathrm{v} / \mathrm{v})$, and $100 \mu \mathrm{L}$ of antibiotics solution (100 IU/mL penicillin, and $100 \mu \mathrm{g} / \mathrm{mL}$ streptomycin), for a total of $8.6 \mathrm{~mL}$ for each lymphocyte culture. The cultures were successively incubated at $37^{\circ} \mathrm{C}$ and under $5 \%$ of $\mathrm{CO}_{2}$ in the air in a humidified atmosphere. After $24 \mathrm{~h}$ of incubation, $8.6 \mu \mathrm{L}$ of $\mathrm{CHT}$ stock solution at concentration of $0.6 \mathrm{mg} / \mathrm{mL}$ were added to the lymphocyte culture in order to reach a final CHT concentration of $0.600 \mu \mathrm{g} / \mathrm{mL}$. Similarly, $8.6 \mu \mathrm{L}$ of CHT stock solution diluted 10, 20, 30 and 40 times with DMSO were added to the lymphocyte cultures in order to reach the final CHT concentrations of $0.060 \mu \mathrm{g} / \mathrm{mL}, \quad 0.030 \mu \mathrm{g} / \mathrm{mL}, \quad 0.020 \mu \mathrm{g} / \mathrm{mL}$ and $0.015 \mu \mathrm{g} / \mathrm{mL}$, respectively. In particular, 0.020 and $0.600 \mu \mathrm{g} / \mathrm{mL}$ represent the ADI and the ARfD concentrations, respectively, established by FAO/WHO for this compound, 0.030 and $0.060 \mu \mathrm{g} / \mathrm{mL}$ intermediate values of these concentrations and $0.015 \mu \mathrm{g} / \mathrm{mL}$ represent the ADI concentration established by Canadian health and welfare agency. Three control cultures were assessed: 1 ) positive control, by adding only MMC (final concentration $0.1 \mu \mathrm{g} / \mathrm{mL}$ culture); 2) $0.1 \%$ DMSO solvent control, obtained by adding $8.6 \mu \mathrm{L}$ of DMSO to the lymphocyte culture; 3) negative control culture without both CHT and DMSO, obtained adding $8.6 \mu \mathrm{L}$ of RPMI medium to the lymphocyte culture. Only for MNi assay, after $44 \mathrm{~h}$ of incubation, cytochalasin-B was added to the cultures at a concentration of $6 \mu \mathrm{g} / \mathrm{mL}$ to block cytokinesis. Similarly, only for CAs assay, to arrest cells in mitosis, colchicine was added at a concentration of $0.06 \mu \mathrm{g} / \mathrm{mL}$ during the last $2 \mathrm{~h}$ of culture.

After $48 \mathrm{~h}$ (for CAs assay) and $72 \mathrm{~h}$ (for MNi assay) of incubation at $37^{\circ}$, the cells were collected by centrifugation and treated for $10 \mathrm{~min}$ with a pre-warmed mild hypotonic solution $(75 \mathrm{mM} \mathrm{KCl})$. After centrifugation and removal of the supernatant, the cells were fixed with a fresh mixture of methanol/acetic acid $(3: 1 \mathrm{v} / \mathrm{v})$. The treatment with the fixative was repeated three times. Finally, the supernatant was discarded and the pellet, dissolved in a minimal volume of fixative, was seeded on the slides to detect CAs and MNi by conventional staining with $5 \%$ Giemsa ( $\mathrm{pH}$ 6.8) prepared in Sörensen buffer.

\subsection{Cytokinesis-block micronucleus assay}

Microscope analysis was performed at $400 \times$ magnification on a light microscope (Dialux 20, Leitz, Germany). MNi, nucleoplasmic bridges (NPB) and nuclear buds (NBUD) were scored in 2000 binucleated lymphocytes with well-preserved cytoplasm per subject (total 12000 binucleated cells per concentration). A total of 2000 lymphocytes per donor per concentration were scored to evaluate the percentage of cells with 1-4 nuclei. The cytokinesis-block proliferation index (CBPI) was calculated, according to the following formula: [1 $\times \mathrm{N} 1]$ $+[2 \times \mathrm{N} 2]+[3 \times(\mathrm{N} 3+\mathrm{N} 4)] / \mathrm{N}$, where $\mathrm{N} 1-\mathrm{N} 4$ represents the number of cells with 1-4 nuclei, respectively, and $\mathrm{N}$ is the total number of cells scored.

\subsection{Chromosomal aberration assays}

Microscope analysis was performed at $1000 \times$ magnification on a light microscope (Dialux 20, Leitz, Germany). For each subject and CHT concentration, 200 well-spread first-division complete metaphases (for 
a total of 1200 metaphases for each dose) were analyzed for the following categories of CAs: gaps (G), chromatid breaks (B'), chromosome breaks (B"), dicentrics (DC), rings (R), tri- or tetra-radials (TR), acentric fragments (AF), rearrangements (Re) and numerical aberrations. Cells containing one of more types of CAs were scored as "aberrant cell" (Ab. C).

In order to determine cytotoxicity, the mitotic index (MI) was calculated from the number of metaphases in 2000 cells analyzed per subject per concentration (a total of 12000 cells per concentration).

\subsection{Statistical analysis}

Comparison of mean values of the percentage of cells with $\mathrm{MNi}$, NPB, NBUD, CBPI, CAs and MI between exposure levels and their controls was assessed by the non-parametric Mann-Whitney test. Statistical calculations were carried out using the SPSS software package program (version 24.0, Inc., Chicago, IL, USA). All $P$ values were two tailed, and $P$ values of $5 \%$ or less were considered statistically significant for all tests carried out.

\section{Results}

\subsection{Effect of CHT on CAs formation}

Table 1 shows values of CAs found in the human peripheral lymphocytes cultured in the presence of different CHT concentrations.

CHT was found to induce seven types of structural CAs (gaps, chromatid and chromosome breaks, dicentric chromosomes, rings, acentric fragments and rearrangements). The most frequent observed aberrations were acentric fragments and chromatid breaks, respectively, whereas no numerical aberrations were found.

In Fig. 1 some examples of observed chromosomal aberrations were showed.

Because of the conflicting opinions about the possibility to consider gaps as indicators of genomic damage (Savage, 2004), we decided to exclude gaps from statistical analysis.

Data obtained indicated that human lymphocytes treated in vitro with CHT significantly $(P=0.004)$ increased the CAs and Ab.C frequencies at all tested concentrations when compared with the solvent control, including the concentration of $0.020 \mu \mathrm{g} / \mathrm{mL}(P=0.009)$ that represents the ADI value established by FAO/WHO for this substance, but with exception of $0.015 \mu \mathrm{g} / \mathrm{mL}$. Moreover, a dose-effect was observed since the regression analysis revealed a significant correlation between the CHT concentrations and the level of CAs $(P<0.001 ; \beta$ coefficient $=0.870)$ and cells with CAs $(P<0.001 ; \beta$-coefficient $=$ $0.873)$. Vice versa, no significant differences were found between the
DMSO solvent-control and the negative control, whereas the cultures treated with the known mutagen MMC showed a significant increase of $\mathrm{CAs}$ and $\mathrm{Ab}$. $\mathrm{C}$ with respect to all $\mathrm{CHT}$ tested concentrations, including the negative and solvent control cultures.

No significant differences in the MI values were observed between DMSO and all tested concentrations of CHT, although at the highest concentration of $0.600 \mu \mathrm{g} / \mathrm{mL}$, the reduction of the MI was very close to the significance values $(P=0.051)$.

Finally, no sexes differences were found in the levels of CAs induced by different CHT concentrations, with exception of MMC although with a borderline $P$-value of 0.046 .

\subsection{Effect of CHT on MNi formation}

To verify both the aneugenic and clastogenic effects of CHT, the MNi test was assessed in parallel with CAs test (Table 2).

Similarly to what we already observed with the CAs assay, our results indicated that CHT significantly increased $(P=0.004)$ the $\mathrm{MNi}$ formation at all tested concentrations (including established ADI value of $0.020 \mu \mathrm{g} / \mathrm{mL}$ ), with exception of $0.015 \mu \mathrm{g} / \mathrm{mL}$. Moreover, a dose-effect was observed since the regression analysis revealed a significant correlation between the CHT concentrations and the frequencies of $\mathrm{MNi}$ and Cells with $\mathrm{MNi}(P<0.001, \beta$-coefficient $=0.863$ and 0.879 for $\mathrm{MNi}$ and Cells with $\mathrm{MNi}$, respectively). No significant differences were observed in the frequencies of NPB and NBUD between the different CHT concentrations and the DMSO solvent control, with exception of the highest concentration of $0.600 \mu \mathrm{g} / \mathrm{mL}(P=0.003$ and $P=0.044$, for NPB and NBUD, respectively).

In Fig. 2 examples of observed bi-, tri- and tetra-nucleated cells with micronuclei, as well as of bi-nucleated cells with NBUD and NPB, were reported.

Also in this case, the DMSO solvent-control cultures did not show any difference with the negative controls $(P=0.089)$, further confirming that at this low concentration DMSO has no cytogenetic effects evaluable by MNi test. MMC showed a significant increase in the MNi formation compared with the negative control $(P=0.004)$, solvent controls $(P=0.004)$ and all tested concentrations of CHT $(P=0.037$ for $0.600 \mu \mathrm{g} / \mathrm{mL}, P=0.006$ for $0.06 \mu \mathrm{g} / \mathrm{mL}$ and $P=0.004$ for 0.030 , 0.020 and $0.015 \mu \mathrm{g} / \mathrm{mL}$ ).

After 48-h exposure, a significant reduction of the CBPI value in cultures treated with CHT was not observed, indicating that at the tested concentrations, CHT does not seem to produce effects on the proliferation index.

Similarly to what observed by CAs assay, females shows highest frequencies of $\mathrm{MNi}$ at all $\mathrm{CHT}$ concentrations tested, although these differences were not significant.

Table 1

Induction of chromosomal aberrations by Chlorothalonil in human lymphocytes in vitro. Number of scored metaphases for each concentration/subject: 200 .

\begin{tabular}{|c|c|c|c|c|c|c|c|c|c|c|c|c|c|c|c|c|}
\hline \multirow[t]{2}{*}{ Test substance $(\mu \mathrm{g} / \mathrm{mL})$} & \multirow[t]{2}{*}{$\mathbf{N}$} & \multicolumn{8}{|c|}{ CAs } & \multirow[t]{2}{*}{ CAs } & \multirow[t]{2}{*}{$\mathrm{CAs}+\mathrm{G}$} & \multirow[t]{2}{*}{ Ab. C } & \multirow[t]{2}{*}{ Ab. $C+G$} & \multirow[t]{2}{*}{ (\%) CAs $/ \mathrm{N} \pm$ S.E. } & \multirow[t]{2}{*}{ (\%) Ab. C/N \pm S.E. } & \multirow[t]{2}{*}{ (\%) MI \pm S.E. } \\
\hline & & G & B' & B” & DC & $\mathbf{R}$ & TR & AF & $\operatorname{Re}$ & & & & & & & \\
\hline NC & 1200 & 3 & 10 & 0 & 0 & 0 & 0 & 2 & 3 & 15 & 18 & 15 & 18 & $1.250 \pm 0.214$ & $1.250 \pm 0.214$ & $5.850 \pm 0.097$ \\
\hline $0.1 \%$ DMSO & 1200 & 5 & 13 & 2 & 0 & 0 & 0 & 3 & 2 & 20 & 25 & 20 & 25 & $1.6700 \pm 0.211$ & $1.6700 \pm 0.211$ & $5.775 \pm 0.063$ \\
\hline MMC $(0.100)$ & 1200 & 29 & 35 & 21 & 7 & 9 & 3 & 40 & 13 & 128 & 157 & 124 & 153 & $10.667 \pm 1.388^{\mathrm{a}}$ & $10.333 \pm 1.160^{\mathrm{a}}$ & $4.675 \pm 0.084^{c}$ \\
\hline CHT $(0.600)$ & 1200 & 5 & 23 & 7 & 6 & 6 & 0 & 27 & 10 & 79 & 84 & 78 & 83 & $6.583 \pm 0.352^{\mathrm{a}}$ & $6.500 \pm 0.288^{\mathrm{a}}$ & $5.450 \pm 0.124$ \\
\hline CHT (0.060) & 1200 & 3 & 20 & 7 & 3 & 1 & 0 & 18 & 10 & 59 & 62 & 59 & 62 & $4.917 \pm 0.417^{\mathrm{a}}$ & $4.917 \pm 0.417^{\mathrm{a}}$ & $5.558 \pm 0.065$ \\
\hline CHT (0.030) & 1200 & 5 & 18 & 8 & 0 & 1 & 0 & 18 & 12 & 57 & 62 & 57 & 62 & $4.750 \pm 0.382^{\mathrm{a}}$ & $4.750 \pm 0.382^{\mathrm{a}}$ & $5.625 \pm 0.038$ \\
\hline CHT (0.020) & 1200 & 4 & 10 & 1 & 3 & 1 & 0 & 19 & 2 & 36 & 40 & 36 & 40 & $3.000 \pm 0.423^{\mathrm{b}}$ & $3.000 \pm 0.423^{\mathrm{b}}$ & $5.767 \pm 0.049$ \\
\hline CHT (0.015) & 1200 & 5 & 10 & 1 & 0 & 0 & 0 & 13 & 1 & 25 & 30 & 25 & 30 & $2.083 \pm 0.327$ & $2.083 \pm 0.327$ & $5.792 \pm 0.040$ \\
\hline
\end{tabular}

$\mathrm{N}$ = total number of scored metaphases; $\mathrm{G}=$ gaps; CAs = chromosomal aberrations; $\mathrm{Ab}$. $\mathrm{C}=$ aberrant cells (cells with 1 or more aberrations); $\mathrm{MI}=\mathrm{Mitotic}$ Index; B': chromatid break; B": chromosome break; DC: dicentric; R: ring; TR = tri-tetraradials; $\mathrm{AF}=$ acentric fragments;Re $=$ rearrangements; S.E. $=$ standard error; NC $=$ Negative Control; MMC $=$ Mitomycin- $\mathrm{C} ; \mathrm{CHT}=$ chlorothalonil.

${ }^{\text {a }} P=0.004$.

b $P=0.009$ and.

c $P=0.004$ (significantly different from the DMSO solvent control, Mann-Whitney test). 

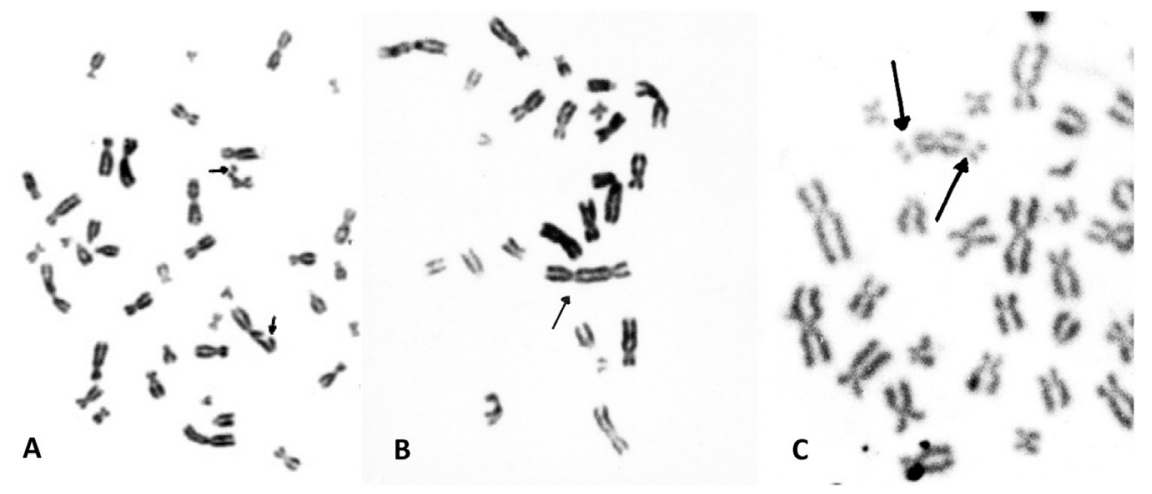

Fig. 1. Complete metaphase carrying chromosomal aberrations (A) and metaphase details (B and C) showing examples of observed chromosomal aberrations (1000 $\times$ magnification, Leitz Dialux 20, Germany). The arrows indicate, respectively: chromatid breaks (Figure A), dicentric chromosome (Figure B) and acentric fragments (Figure C).

Table 2

Induction of micronuclei produced by Chlorothalonil in human lymphocytes in vitro. Number of scored binucleated cells for each concentration/subject: 2000 .

\begin{tabular}{|c|c|c|c|c|c|c|c|c|c|c|c|c|}
\hline \multirow[t]{2}{*}{$\begin{array}{l}\text { Test } \\
\text { substance } \\
(\mu \mathrm{g} / \mathrm{mL})\end{array}$} & \multirow[t]{2}{*}{$\mathbf{N}$} & \multicolumn{4}{|c|}{$\begin{array}{l}\text { Distribution of BNCs } \\
\text { according to the number of } \\
\text { MNi }\end{array}$} & \multirow[t]{2}{*}{ MNi } & \multirow[t]{2}{*}{ Ab. C } & \multirow[t]{2}{*}{ MNi/N \pm S.E. (\%) } & \multirow[t]{2}{*}{ Ab. $\mathrm{C} / \mathrm{N} \pm$ S.E. $(\%)$} & \multirow[t]{2}{*}{ CBPI \pm S.E } & \multirow[t]{2}{*}{$\begin{array}{l}\text { BNCs with NPB } \\
(\%)\end{array}$} & \multirow[t]{2}{*}{$\begin{array}{l}\text { BNCs with NBUD } \\
(\%)\end{array}$} \\
\hline & & 1 & 2 & 3 & 4 & & & & & & & \\
\hline NC & 12000 & 21 & 1 & 0 & 0 & 23 & 22 & $0.192 \pm 0.024$ & $0.183 \pm 0.021$ & $1.680 \pm 0.041$ & $0.333 \pm 0.105$ & $0.750 \pm 0.112$ \\
\hline $0.1 \%$ DMSO & 12000 & 33 & 1 & 0 & 0 & 35 & 34 & $0.292 \pm 0.040$ & $0.283 \pm 0.036$ & $1.600 \pm 0.056$ & $0.417 \pm 0.154$ & $0.917 \pm 0.154$ \\
\hline MMC (0.100) & 12000 & 235 & 14 & 3 & 1 & 276 & 253 & $2.300 \pm 0.211^{\mathrm{a}}$ & $2.108 \pm 0.175^{\mathrm{a}}$ & $1.344 \pm 0.015^{\mathrm{b}}$ & $2.500 \pm 0.408^{c}$ & $2.833 \pm 0.441^{\mathrm{e}}$ \\
\hline CHT $(0.600)$ & 12000 & 174 & 8 & 0 & 2 & 198 & 188 & $1.650 \pm 0.178^{\mathrm{a}}$ & $1.567 \pm 0.147^{\mathrm{a}}$ & $1.499 \pm 0.038$ & $2.000 \pm 0.183^{\mathrm{d}}$ & $1.500 \pm 0.183^{\mathrm{f}}$ \\
\hline CHT (0.060) & 12000 & 153 & 6 & 0 & 1 & 169 & 160 & $1.408 \pm 0.137^{\mathrm{a}}$ & $1.333 \pm 0.103^{\mathrm{a}}$ & $1.531 \pm 0.027$ & $0.917 \pm 0.154$ & $1.167 \pm 0.105$ \\
\hline CHT (0.030) & 12000 & 119 & 4 & 1 & 0 & 130 & 124 & $1.083 \pm 0.101^{\mathrm{a}}$ & $1.033 \pm 0.080^{\mathrm{a}}$ & $1.543 \pm 0.012$ & $0.667 \pm 0.105$ & $1.083 \pm 0.154$ \\
\hline CHT $(0.020)$ & 12000 & 72 & 1 & 0 & 0 & 74 & 73 & $0.617 \pm 0.061^{\mathrm{a}}$ & $0.608 \pm 0.061^{\mathrm{a}}$ & $1.571 \pm 0.063$ & $0.500 \pm 0.129$ & $1.000 \pm 0.129$ \\
\hline CHT (0.015) & 12000 & 41 & 0 & 0 & 0 & 41 & 41 & $0.342 \pm 0.020$ & $0.342 \pm 0.020$ & $1.586 \pm 0.057$ & $0.417 \pm 0.154$ & $1.000 \pm 0.183$ \\
\hline
\end{tabular}

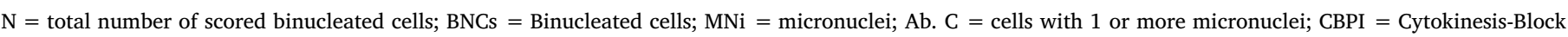

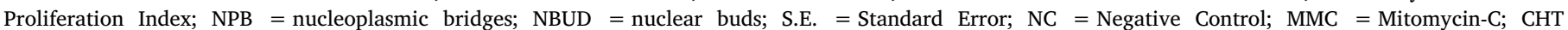
$=$ Chlorothalonil.

${ }^{\text {a }} P=0.004$.

b $P=0.016$.

c $P=0.005$.

${ }^{\mathrm{d}} P=0.003$.

e $P=0.005$, and.

f $P=0.044$ (significantly different from the DMSO solvent control, Mann-Whitney test).

\section{Discussion}

Exposure to pesticides is known to be an important environmental risk factor associated with the development of cancer (Alavanja et al., 2005). However, insufficient data are present in literature about the genotoxicity of many commercially available pesticides. In particular, the genotoxic potential of CHT was evaluated in different in vitro and in vivo studies but observed data were, in some cases, contradictory (Lebailly et al., 1997; Vigreux et al., 1998).

Results obtained in the present study evidenced a possible clastogenic and/or aneugenic effect of the CHT on human lymphocytes, also at the concentration of $0.020 \mu \mathrm{g} / \mathrm{mL}$ that represents the ADI value established for humans by FAO/WHO (2010). Our data seem to be concordant with results obtained by other authors with different cell lines and/or different assays. Lebailly et al. (1997), by a SCGE assay, observed a significant effect of CHT on human peripheral blood lymphocytes in terms of cell viability and DNA-damage. Similarly, CHT was found to induce SCEs and CAs in vitro in Chinese hamster ovary cells (Dearfield et al., 1993), whereas in vivo this increase of the DNA damage was observed in rat, mouse and Chinese hamster only after a chronic treatment for 5 successive days, but not after a single dose treatment (Dearfield et al., 1993). However, it should be emphasized that all data about CHT genotoxicity should be interpreted with particular attention also in view of the fact that, in pesticide formulations used by farmers, CHT is frequently associated to other pesticides, such as carbendazim, that are known to enhance the genotoxic effect of CHT on human PBL (Lebailly et al., 1997).
Chlorothalonil and other polychlorinated compounds like polychlorinated biphenyls, polychlorinated dibenzo-p-dioxins and polychlorinated dibenzofurans, represent persistent organic contaminants of anthropic or natural origin, ubiquitously found in the environment and with the ability to bioaccumulate and biomagnify in food chains, causing the decline or disappearance of wild populations (Bruns-Weller et al., 2010). Like chlorothalonil, most of these polychlorinated compounds also showed genotoxic properties. For example, 1,2-dichloroethylene, 1,1,2-trichloroethane, 1,3-dichloropropane, and 1,1,3trichloropropene, widely used as solvents and degreasing agents in industry, were found to induce MNi and DNA damage in human lymphocytes (Tafazoli and Kirsch-Volders, 1996). Similarly, 2,2',4,4',5,5'-

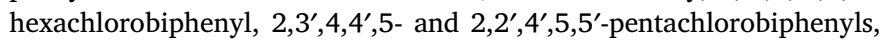
were found to induce MNi and DNA breaks in fish RTG-2 cells (Marabini et al., 2011). The same polychlorinated biphenyls were found to affect the female reproductive system in humans, and some of these, like chlorinated bisphenol-A, were associated with metabolic conditions, such as obesity, lipid accumulation and type 2 diabetes mellitus (Andra et al., 2015). Moreover, dicloran (2,6-dichloro-4-nitroaniline), an aromatic amine commonly used as an agricultural fungicide throughout the Southern and Western United States, was found to be mutagen in Salmonella strains TA98 and TA100 (de Oliveira et al., 2009). Another aromatic fungicide, the $p$-cresol, at concentrations of 1.6 and $3.2 \mathrm{mM}$ was found to be genotoxic toward HT-29 Glc-/+ and LS-174T human intestinal cells (Andriamihaja et al., 2015), whereas the fungicide hexachlorobenzene was found to be able to induce DNA damage and oxidative stress in human intestinal Caco- 2 cells, also at the 


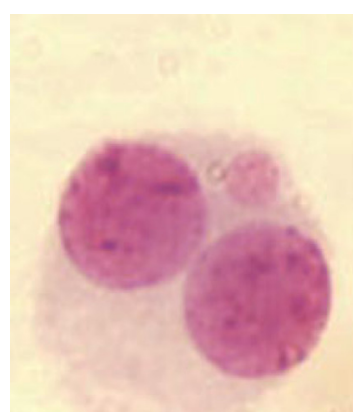

A

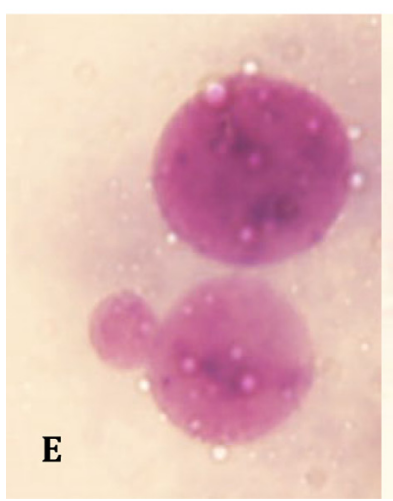

B

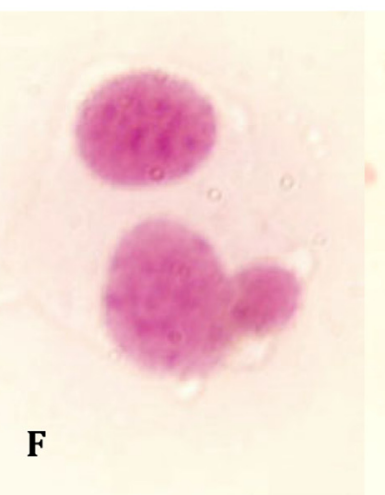

C

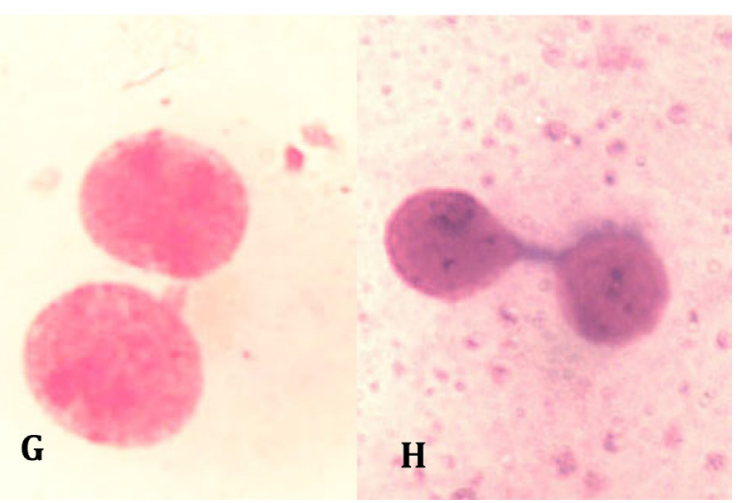

Fig. 2. Examples of micronuclei observed in binucleated cells (A-B), in trinucleated cell (C) and in tetranucleated cell (D) $(1000 \times$ magnification, Leitz Dialux 20 , Germany). According to standardized procedures, micronuclei of tri- and tetra-nucleated cells were not scored in the evaluation of the total genomic damage. Examples of binucleated cells with nuclear buds (E-F) and bi-nucleated cells with nucleoplasmic bridges (G-H) are also reported.

low concentrations of 0.4 and $400 \mathrm{nM}$ (Chalouati et al., 2015). Increased levels of MNi were observed also in in vivo studies, for example in several fish species after exposure to commercial polychlorinated biphenyls in contaminated areas, as well as abnormal karyotypes were observed in workers exposed to these compounds (Ludewig and Robertson, 2013).

The mechanisms underlying genotoxic potential of CHT alone or in complexation with other compounds are unknown, although it was found that exposure to CHT may trigger cytotoxic and inflammatory processes. These last were found able to induce DNA damage and the loss of cellular membrane integrity (Wilkinson and Killeen, 1996) as well as cytogenetic damage (Higashimoto et al., 2006; Santovito et al., 2016). In this sense, it is our opinion that the increase of cytogenetic damage observed by our group with both CAs and MNi assays, and by other groups with different assays and cell lines, requires further investigations and should pushes towards the adoption of lower reference limits. Indeed, increased CAs and MNi frequencies in peripheral blood lymphocytes have been positively associated with increased cancer risk and early events in carcinogenesis, respectively (Bonassi et al., 2004, 2011). Moreover, CHT was found to have in vitro tumor promoting effects in Syrian hamster embryo cells (Bessi et al., 1999), whereas, in vivo, chronic dietary treatment with CHT was found to causes in rodents (rats and mice) increased incidence of papillomas and carcinomas of the forestomach squamous epithelium and adenomas and carcinomas of the renal proximal tubule epithelium (Wilkinson and Killeen, 1996). All these considerations and the fact that also in our study we do not observed clastogenic/aneugenic effects at the CHT concentration of $0.015 \mu \mathrm{g} / \mathrm{mL}$, seem to justify the Canadian health and welfare agency that, in contrast to FAO/WHO, established for CHT a lower ADI-value of 0-0.015 mg/kg/day (HWC, 1994).

The MI and the CBPI did not show any significant difference at all tested concentrations with respect to the solvent control, although at concentration of $0.600 \mu \mathrm{g} / \mathrm{mL}$ the $P$-values of both indices were borderline ( $P=0.051$ for $\mathrm{MI}$ and $P=0.078$ for $\mathrm{CBPI}$ ), indicating that the CHT cytotoxicity threshold could be close to this concentration value. These data differ from those found by other authors for other fungicides or insecticides (Kocaman et al., 2014; Yüzbașioğlu et al., 2006), although it should be emphasized that these authors evaluated the MI at xenobiotic concentrations much higher than those tested in the present work.

Finally, as the role of sex, in the present study females showed higher levels of genomic damage than males, although with non-statistically significant values. The only exceptions were represented by MMC in the CAs assay, although with a borderline $P$-value of 0.046 . However, it should be emphasized that the small sample size, typical of an in vitro study, does not allow to drawn definitive conclusions. In our previous in vivo studies involving a larger number of subjects, the results related to a possible role of sex in determining the level of genomic damage were conflicting. Indeed, a positive association between the frequencies of CAs, sister chromatid exchanges and sex was found by our group in two control populations $(n=101$ and $n=230$, respectively), with females showing highest levels of genomic damage (Santovito et al., 2017), whereas in another study this association was not observed (Santovito et al., 2016)

\section{Conclusion}

The results herein reported showed cytogenetic effects of CHT on cultured human lymphocytes in terms of increased CAs and MNi frequencies. Although simple experimental models like mammalian and bacterial cells cannot accurately mimic the complex in vivo kinetics of xenobiotic compounds, results we obtained with CHT point to the necessity of further investigations in order to establish the real genotoxic potential of this compound, alone and/or in association with other compounds, and, eventually, the adoption of more stringent measures able to reduce the presence of this compound in the environment and to 
minimize the adverse effects of the CHT exposure on human health.

\section{Acknowledgments}

This research work was financially supported by Italian Minister of University and Public Education (grant "ex 60\%").

\section{Conflict of interest}

The authors declare that they have no conflict of interest

\section{Ethical approval}

All procedures performed in studies involving human participants were in accordance with the ethical standards of the institutional and/ or national research committee and with the 1964 Helsinki declaration and its later amendments or comparable ethical standards.

\section{Informed consent}

Informed consent was obtained from all individual participants included in the study.

\section{References}

Alavanja, M.C., Bonner, M.R., 2005. Pesticides and human cancers. Cancer Investig. 23, $700-711$.

Andra, S.S., Charisiadis, P., Arora, M., van Vliet-Ostaptchouk, J.V., Makris, K.C., 2015. Biomonitoring of human exposures to chlorinated derivatives and structural analogs of bisphenol A. Environ. Int. 85, 352-379.

Andriamihaja, M., Lan, A., Beaumont, M., Audebert, M., Wong, X., Yamada, K., Yin, Y., Tomé, D., Carrasco-Pozo, C., Gotteland, M., Kong, X., Blachier, F., 2015. The deleterious metabolic and genotoxic effects of the bacterial metabolite p-cresol on colonic epithelial cells. Free Radic. Biol. Med. 85, 219-227.

Arinaitwe, K., Kiremire, B.T., Muir, D.C.G., Fellin, P., Li, H., Teixeira, C., Mubiru, D.N., 2016. Legacy and currently used pesticides in the atmospheric environment of Lake Victoria, East Africa. Sci. Total Environ. 543, 9-18.

Bessi, H., Cossu-Leguille, C., Zaïd, A., Vasseur, P., 1999. Effects of Chlorothalonil on Glutathione and Glutathione-Dependent Enzyme Activities in Syrian Hamster Embryo Cells. B Environ. Contam. Toxicol. 63, 582-589.

Bonassi, S., Znaor, A., Norppa, H., Hagmar, L., 2004. Chromosomal aberrations and risk of cancer in humans: an epidemiologic perspective. Cytogenet. Genome Res. 104, 376-382.

Bonassi, S., El-Zein, R., Bolognesi, C., Fenech, M., 2011. Micronuclei frequency in peripheral blood lymphocytes and cancer risk: evidence from human studies. Mutagenesis 26, 93-100.

Bruns-Weller, E., Knoll, A., Heberer, T., 2010. High levels of polychlorinated dibenzodioxins/furans and dioxin like-PCBs found in monitoring investigations of sheep liver samples from Lower Saxony, Germany. Chemosphere 78, 653-658.

Chalouati, H., Boutet, E., Metais, B., Fouche, E., Ben Sâad, M.M., Gamet-Payrastre, L., 2015. DNA damage and oxidative stress induced at low doses by the fungicide hexachlorobenzene in human intestinal Caco-2 cells. Toxicol. Mech. Methods 25, 448-458.

de Oliveira, D.P., Sakagami, M., Warren, S., Kummrow, F., de Aragão Umbuzeiro, G., 2009. Evaluation of dicloran's contribution to the mutagenic activity of Cristais river, Brazil, water samples. Environ. Toxicol. Chem. 28, 1881-1884.

Dearfield, K.L., Stack, H.F., Quest, J.A., Whithing, R.J., Waters, M.D., 1993. A survey of PArOPP and open literature data on selected pesticide chemicals tested for mutagenicity - I. Introduction and first ten chemicals. Mutat. Res. 297, 197-233.

Du Gas, L.M., Ross, P.S., Walker, J., Marlatt, V.L., Kennedy, C.J., 2017. Effects of atrazine and chlorothalonil on the reproductive success, development, and growth of early life stage sockeye salmon (Oncorhynchus nerka). Environ. Toxicol. Chem. 36, 1354-1364.

EPA, 1999. Chlorothalonil 〈https://archive.epa.gov/pesticides/reregistration/web/pdf/ 0097fact.pdf $>$. (Accessed on 14 December 2017).

FAO/WHO, 1992. Pesticide Residues in Food. FAO Plant Production and Protection. Paper No. 116, pp. 29-31.

FAO/WHO, 2010. Pesticide Residues in Food. 〈http://www.fao.org/fileadmin/ templates/agphome/documents/Pests_Pesticides/JMPR/Report10/JMPR_2010_ contents.pdf $\rangle$. (Accessed on 14 December 2017).

Fenech, M., Knasmueller, S., Bolognesi, C., Bonassi, S., Holland, N., Migliore, L., Palitti,
F., Natarajan, A.T., Kirsch-Volders, M., 2016. Molecular mechanisms by which in vivo exposure to exogenous chemical genotoxic agents can lead to micronucleus formation in lymphocytes in vivo and ex vivo in humans. Mutat. Res. 770 (PtA), 12-25.

Gallo, A., Tosti, E., 2015. Reprotoxicity of the antifoulant chlorothalonil in ascidians: an ecological risk assessment. PLoS One 10, e0123074.

Garcia-Sagredo, J.M., 2008. Fifty years of cytogenetics: a parallel view of the evolution of cytogenetics and genotoxicology. Biochim. Biophys. Acta 1779, 363-375.

Guerreiro, A.D.S., Rola, R.C., Rovani, M.T., Costa, S.R.D., Sandrini, J.Z., 2017. Antifouling biocides: impairment of bivalve immune system by chlorothalonil. Aquat. Toxicol. 189, 194-199.

Higashimoto, T., Panopoulos, A., Hsieh, C.L., Zandi, E., 2006. TNF induces chromosomal abnormalities independent of ROS through IKK, JNK, p38, and caspase pathways. Cytokine 34, 39-50.

HWC Health and Safety Status Report, 1994. Chlorothalonil. Health Protection Branch, Health and Welfare Canada, Ottawa. 〈http://ceqg-rcqe.ccme.ca/download/en/111〉. (Accessed on 14 December 2017).

IARC (International Agency for Research on Cancer), 1999. Some Chemicals that Cause Tumours of the Kidney or Urinary Bladder in Rodents and Some Other Substances. IARC Monographs on the Evaluation of Carcinogenic Risks to Humans 73, pp. 183-184.

Kocaman, A.Y., Rencüzoğullari, E., Topaktaş, M., 2014. In vitro investigation of the genotoxic and cytotoxic effects of thiacloprid in cultured human peripheral blood lymphocytes. Environ. Toxicol. 29, 631-641.

Lebailly, P., Vigreux, C., Godard, T., Sichel, F., Bar, E., LeTalaër, J.Y., Henry-Amar, M., Gauduchon, P., 1997. Assessment of DNA damage induced in vitro by etoposide and two fungicides (carbendazim and chlorothalonil) in human lymphocytes with the comet assay. Mutat. Res. 375, 205-217.

Lebailly, P., Vigreux, C., Lechevrel, C., Ledemeney, D., Godard, T., Sichel, F., LeTalaër, J.Y., Henry-Amar, M., Gauduchon, P., 1998. DNA damage in mononuclear leukocytes of farmers measured using the alkaline comet assay: modifications of DNA damage levels after a one-day field spraying period with selected pesticides. Cancer Epidemiol. Biomarker 7, 929-940.

Lensen, G., Jungbauer, F., Gonçalo, M., Coenraads, P.J., 2007. Airborne irritant contact dermatitis and conjunctivitis after occupational exposure to chlorothalonil in textiles. Contact Dermat. 57, 181-186.

Lensen, G., Coenraads, P.J., Jungbauer, F., Schuttelaar, M.L., 2011. Contact dermatitis caused by chlorothalonil on imported roses: irritant or allergic reaction? Contact Dermat. 65, 50-51.

Ludewig, G., Robertson, L.W., 2013. Polychlorinated biphenyls (PCBS) as initiating agents in hepatocellular carcinoma. Cancer Lett. 334, 46-55.

Marabini, L., Calò, R., Fucile, S., 2011. Genotoxic effects of polychlorinated biphenyls (PCB 153, 138, 101, 118) in a fish cell line (RTG-2). Toxicol. Vitro 25, 1045-1052.

Mozzachio, A.M., Rusiecki, J.A., Hoppin, J.A., Mahajan, R., Patel, R., Beane-Freeman, L., Alavanja, M.C., 2008. Chlorothalonil exposure and cancer incidence among pesticide applicator participants in the agricultural health study. Environ. Res. 108, 400-403.

Penagos, H., Ruepert, C., Partanen, T., Wesseling, C., 2004. Pesticide patch test series for the assesment of allergic contact dermtitis among banana plantation workers in Panama. Dermatitis 15, 137-145.

Santovito, A., Cervella, P., Chiarizio, M., Meschiati, G., Delsoglio, M., Manitta, E., Picco, G., Delpero, M., 2016. Relationships between cytokine (IL-6 and TGF-b1) gene polymorphisms and chromosomal damage in hospital workers. J. Immunotoxicol. 13, 314-323.

Santovito, A., Gendusa, C., Cervella, P., 2017. Evaluation of baseline frequency of sister chromatid exchanges in an Italian population according to age, sex, smoking habits, and gene polymorphisms. Am. J. Hum. Biol. 29, 1-10.

Savage, J.R., 2004. On the nature of visible chromosomal gaps and breaks. Cytogenet. Genome Res. 104, 46-55.

Tafazoli, M., Kirsch-Volders, M., 1996. In vitro mutagenicity and genotoxicity study of 1,2-dichloroethylene, 1,1,2-trichloroethane, 1,3-dichloropropane, 1,2,3-trichloropropane and 1,1,3-trichloropropene, using the micronucleus test and the alkaline single cell gel electrophoresis technique (comet assay) in human lymphocytes. Mutat. Res. /Genet. Toxicol. 371, 185-202.

Vigreux, C., Poul, J.M., Deslandes, E., Lebailly, P., Godard, T., Sichel, F., Henry-Amar, M., Gauduchon, P., 1998. DNA damaging effects of pesticides measured by the single cell gel electrophoresis assay (comet assay) and the chromosomal aberration test, in CHOK1 cells. Mutat. Res. 419, 79-90.

Wilkinson, C.F., Killeen, J.C., 1996. A mechanistic interpretation of the oncogenicity of chlorothalonil in rodents and an assessment of human relevance. Regul. Toxicol. Pharm. 24, 69-84.

Wu, X., Yin, Y., Wang, S., Yu, Y., 2014. Accumulation of chlorothalonil and its metabolite, 4-hydroxychlorothalonil, in soil after repeated applications and its effects on soil microbial activities under greenhouse conditions. Environ. Sci. Pollut. Res 21, 3452-3459.

Yu, S., Wages, M.R., Cobb, G.P., Maul, J.D., 2013. Effects of chlorothalonil on development and growth of amphibian embryos and larvae. Environ. Pollut. 181, 329-334.

Yüzbașioğlu, D., Celik, M., Yilmaz, S., Unal, F., Aksoy, H., 2006. Clastogenicity of the fungicide afugan in cultured human lymphocytes. Mutat. Res. 604, 53-59. 